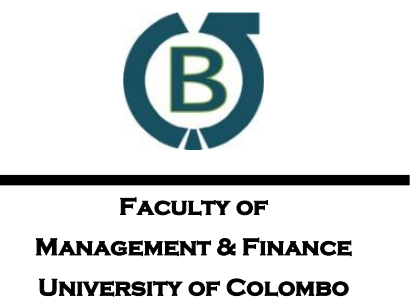

\title{
Dynamics of Voter Satisfaction: Empirical Investigation of Young Indian Voters
}

\author{
Mohd Danish Kirmani ${ }^{\mathrm{a}} \bowtie$, Nirupa Lakshmia ${ }^{\mathrm{a}}$, Faiz Hasan ${ }^{\mathrm{b}}$, Yogendra Pal \\ Bhardwaj $^{\mathrm{c}}$ \\ ${ }^{a}$ Department of Management Studies, Galgotias College of Engineering and Technology, \\ India \\ ${ }^{b}$ IIM Indore, India
}

'Institute of Business Management, GLA University, India

\begin{abstract}
The objective of the present study was to identify factors that sensitise voters towards the political system and stimulate them for active participation in the election process. The study also aimed to examine the role of these factors in increasing the voter satisfaction. Data was generated from a sample of 194 young voters. One contribution of the study was to validate a scale measuring political sensitivity of voters. Findings also revealed that the higher the economic and global consideration (EGC) among voters the lesser will be their satisfaction with the existing political system. The predictors of EGC are observed to be social considerations (SC) and perceived risk (PR). Findings of the study also suggest that higher perceived knowledge of voters will lead to increased involvement in the political system. The study is pioneering as it initiates efforts for comprehensive analyses of the Indian voters for better understanding of factors that affect their political sensitivity.
\end{abstract}

Keywords: India, Voter Satisfaction, Young Voters

Received:

30 July 2019
Accepted revised version:

31 October 2019
Published:

31 December 2019

Suggested citation: Kirmani, M. D., Lakshmi, N., Hasan, F., \& Bhardwaj, Y. P (2019). Dynamics of voter satisfaction: Empirical investigation of young Indian voters. Colombo Business Journal. (10)2, 75-102

DOI: http://doi.org/10.4038/cbj.v10i2.51

(C) 2019 The Authors. This work is licenced under a Creative Commons Attribution 4.0 International Licence which permits unrestricted use, distribution, and reproduction in any medium, provided the original work is properly cited.

凶kirmani87@gmail.com: (iD https://orcid.org/0000-0002-9641-8326 


\section{Introduction}

India, being the largest democracy in the world and having around 850 million electorates, offer unique political scenario due to two factors. First, contrary to the international trends, Indian population is a young population. The proportion of 'youth' in total Indian population is 35\% (Lu, Yiu, \& Soman, 2016; Central Statistics Office, 2017). More specifically, around 50\% of the Indian population is under the age of 25 years (Heslop, 2014). This trend is expected to remain same in future also. According to the estimates of the National Commission on Population (2006), the average age in India would be 31.39 years in 2026. In the 2019-General Elections in India, around 84 million first-time voters were eligible to exercise their right to vote (Deka, 2019; Jain, 2019).

Second, the recently held elections indicate that the young Indian population participates enthusiastically in elections (Deka, 2019). According to the estimates of a report prepared by Sahu (2014) and released by Research and Information Division of Lok Sabha Secretariat, around 66\% of Indian voters exercised their right to vote in the 2014-General Election. An interesting observation in this election is the active participation of young and 'first-time' voters (Basu \& Mishra, 2014). Thus, strategizing for elections in India is not possible without proper understanding of young voters (Vaishnay, 2015; Joshi \& Kunduri, 2017).

With regard to election strategies, a new trend has been observed in the global context where politicians are using pure marketing concepts in reaching out to their voters (O'Shaughnessy 2001). Voter satisfaction is one such concept adapted from the concept of consumer satisfaction. Fundamentally, consumer satisfaction reflects the feeling that consumers show after consumption of products (Giese \& Cote, 2000; O'Cass \& Pecotich, 2005). It is considered as an outcome of various post purchase events (Gieese \& Cote, 2000). In the context of voting, previous researchers have suggested that higher voter satisfaction results in more participation of voters during elections (Hadjar \& Beck, 2010). Hence, it is imperative for politicians to have indepth understanding of the factors that lead to higher voter satisfaction and hence, contribute in active voter participation in the election process (Banerjee \& Ray Chaudhuri, 2016; Ehrenberg 1997; Henn, Weinstein, \& Forest, 2005; O’Cass \& Pecotich, 2005; Winchester, Hall, \& Binney, 2015).

Globally, politicians are making attempts to unravel concerns and preferences of voters for the purpose of designing effective election campaigns (Fyfe, 2009; Henn et al., 2005; Jasperson \& Yun, 2007; Manning, 2010; Vaishnav, 2015; Winchester et 
al., 2015). In this regard, earlier studies have suggested that voters rely on critical and rational thinking to arrive at election decisions (Falkowski \& Cwalina, 2012; Peng \& Hackley, 2009). In fact, the researchers have opined that the decision of voters to elect a political party or a leader is the reflection of their basic needs (Banerjee \& Ray Chaudhuri, 2016; Burton \& Netemeyer, 1992; Harris \& Lock, 2010; O'Cass \& Pecotich, 2005; Palda, 1975; Winchester et al., 2015).

However, there is limited literature available to understand factors crucial for voter satisfaction and their concerns with key political issues such as global reputation of the country, its economic condition, prevailing condition of underprivileged sections of the society, etc. In the Indian context, the researchers have paid little attention to understand young Indian voters (Joshi \& Kunduri, 2017). The earlier studies have ordinarily focused on general issues such as party performance, election campaigns, media involvement and election results (Beg, 2017; Bhalotra, ClotsFigueras, Cassan, \& Iyer, 2014; Harris, 2015; Heath, Verniers, Kumar, 2015; Kapur \& Nangia, 2015; Vaishnav \& Swanson, 2015). In majority of the earlier studies, the results are based on past election data (Bhalotra et al., 2014; Harris, 2015; Heath et al., 2015; Kapur \& Nangia, 2015; Vaishnav \& Swanson, 2015; Beg, 2017). Hence, there is a need for empirical studies based on direct responses from voters. Moreover, there is a need to identify the factors that results in voter satisfaction with the existing political system in the country. In light of this, objective of the present study was to identify the factors that sensitise voters towards the political system and stimulate them for active participation in the election process. The study also aimed to examine the role of these factors in increasing the voter satisfaction. This study is pioneering in the sense that it initiates efforts for comprehensive analyses of Indian voters.

\section{Literature Review and Conceptualization}

Researchers across the globe have examined the voter concerns and preferences that can lead to voter satisfaction with the existing political system. In fact, the domain of voter concerns and preferences grabbed the interests of researchers for the first time in the 1952 USA elections (Rothschild, 1978; Winchester et al., 2015). Since then, the researchers have examined this domain of study employing different approaches (Cwalina, Falkowski, Newman, \& Vercic, 2004; Newman \& Sheth, 1985; O'Cass, 2003 O'Cass \& Pecotich, 2005).

Researchers have opined that the concerns and preferences crucial for voter satisfaction depend upon the level of enduring and situational involvement of voters in the election process (Ben-Ur, 2007; Gad, 2014; Banerjee \& Ray Chaudhuri, 2016). 
Enduring involvement refers to the general interest of voters in the politics of their country whereas situational involvement refers to the interest generated among voters by the specific election campaigns (Ben-Ur, 2007). The higher enduring and situational involvement leads to better response from voters (Antil, 1984; Burton \& Netemeyer, 1992; Ben-Ur, 2007; Faber, Tims, \& Schmitt, 1993; Rothschild, 1978; Winchester et al., 2015). In fact, the high level of enduring and situational involvement of voters also enable them to use a combination of constructive and realistic approach for decision making during elections (Ehrenberg, 1991; Erasmus, Boshoff, \& Rousseau, 2001; Peng \& Hackley, 2009; Zaichkowsky, 1985). In constructive approach, voters make rational decisions by using specific information; while in realistic approach political decisions of voters depend on the prevailing issues in the country (Falkowski \& Cwalina, 2012; Ki \& Hon, 2012).

Broadly, concerns and preferences crucial for higher voter satisfaction can be explained by using the three models (Antunes, 2010): the sociological model (also identified as School of Columbia), the model of economic theory (also referred as School of Rochester) and the psychological model (referred as School of Michigan). The sociological model, explained by Lazarsfeld, Berelson, and Gaudet (1944), highlighted the influence of social factors (such as socio-economic status, religion and area of residence) on the voting decisions. On the other hand, the model of economic theory was based on the premises of rationality, self-interest, consistency and uncertainty (Downs, 1957). According to economic theory, decision making by voters about different options available is guided by rationality and self-interest with a certain level of consistency and uncertainty involved (Downs, 1957).

The psychological model, explained by Campbell, Converse, Miller, and Stokes (1960), suggested that the party partisanship is one of the important factors for affecting the voter behaviour. According to Campbell et al. (1960), voters prefer the ideology of one political party over that of other party. The party partisanship of voters was explained by Campbell et al. (1960) by linking long-term factors (such as race, ethnicity, gender, social class, occupation, values and partisanship) with shortterm factors (candidate evaluation and issue perceptions). According to Campbell et al. (1960), long-term factors create party identification among the voters that guide their short-term choices of candidate evaluation and issue perception. In the context of bi-party system, researchers have suggested that the psychological model explained by Campbell et al. (1960) is still very crucial in explaining political sensitivity of voters (Antunes, 2010; Dalton, 1984, 2000, Fiorina 1981; Franklin, Mackie, \& Valen, 1992; Kiewiet, 1983; Wattenberg, 1994). 
In the context of countries where multiple parties are allowed to contest the elections, researchers have attempted to identify factors that are linked to higher voter involvement and their satisfaction with the existing political process (Beg, 2017; Cwalina et al, 2004; Cwalina, Falkowski, \& Newman, 2010; Harris, 2015; Newman, 1999, 2002; Newman \& Sheth, 1985, 1987). These factors and the relationships among these factors have been discussed below

\section{Voter Involvement (VI) and Voter Satisfaction (VS)}

High involvement of voters assists them to make wise political decisions that result into the election of an efficient government (Richins \& Bloch, 1991). Also, higher voter involvements enforce governments to improve their functioning (Geys, Heinemann, \& Kalb, 2010). Thus, it is expected that high voter involvement will result into increase in voter satisfaction. In this regard, O'Cass (2002) comprehensively examined the role of higher voter involvement on increasing the voter satisfaction and suggested a positive linkage between the two variables. O'Cass and Natarajan (2003) emphasized that higher voter involvement infuse confidence about the existing political process that leads to higher satisfaction among voters. The above discussion helped in formulating the following hypothesis:

$\mathrm{H}_{1}$ : Voter Involvement (VI) positively affects Voter Satisfaction (VS)

\section{Perceived Knowledge (PK) and Voter Involvement (VI)}

One factor that is considered as crucial for influencing voter involvement in the election process is the perceived knowledge of voters. The construct perceived knowledge assist in capturing the awareness of voters about the issues related to national and international politics. An informed voter is expected to be more committed to democratic principles and hence, more sensitive to the political discourse in the country (Delli Carpini \& Keeter, 1996). They are likely to be engaged in various forms of political participations (Banwart, 2007; O'Cass \& Pecotich, 2005). Stockemer and Rocher (2017) had even suggested that increase in political knowledge can significantly increase turnout of young voters in the elections. Thus, the following hypothesis was formulated:

$\mathrm{H}_{2}$ : Perceived knowledge (PK) positively affects voter involvement (VI) in the election process

\section{Religious and Caste Considerations (RCC) and Voter Involvement (VI)}

Previous researchers have opined that the voters are more attractive to candidates who are similar to them (Blalock, 1967; Chandra, 2009; Cook, 1994; Dolan, 1998; 
Heath et al., 2015; Huddy \& Terkildsen, 1993; Tate, 1993). More specifically, voters are more inclined to elect candidates belonging to caste and religion similar to their caste and religion. This is also supported in the observation by Cwalina et al. (2010) that emotions (such as those related to religion and caste) can be crucial in stimulating voters towards the political process. In this regard, the construct Religious and Caste Considerations (RCC) measures the voter concerns regarding the issues related to their religion and caste. This construct is particularly important in the Indian context where the religion and caste affiliations always remain at the focal point in the voter decision making (Beg, 2017; Bhalotra et al., 2014; Harris, 2015; Heath et al., 2015; Huber \& Suryanarayan, 2016; Pande, 2003). Heath et al. (2015) suggested that religious affiliations affect election-related decisions of Indian voters. The other researchers such as Bhalotra et al. (2014), Harris (2015) and Beg (2017) also used religious identity as a factor in their study on political marketing in India and asserted that religious concerns can increase voter involvement. Similarly, researchers such as Banerjee Green, McManus, and Pande (2014) and Huber and Suryanarayan (2016) opined that the caste concerns of Indian voters also influence their involvement in the election process. Recently, Vaishnav (2015) also emphasized the importance of religious and caste identity of politicians in Indian elections. Based on the above discussion, the following hypothesis was formulated:

$\mathrm{H}_{3}$ : Religious and caste considerations (RCC) positively affect voter involvement (VI) in the election process

\section{Economic and Global Considerations (EGC) and Voter Satisfaction (VS)}

The construct EGC is intended to measure concern of voters related to prevailing economic policies and impact of these policies on global reputation of the country (Acs \& Szerb, 2009; Bengoa \& Sanchez-Robles, 2003; Hazelkorn, 2014). The economic considerations of voters are considered to be crucial for influencing election results in the global context (Anderson, 2007; Lewis-Beck \& Stegmaier, 2000). In the Indian context, Vaishnav and Swanson (2015) have suggested that voters make election decisions after careful evaluation of economic policies of incumbent governments. This suggests that the perception of voters about economic policies of successive governments could be a predictor of their satisfaction with the existing political system in the country. Moreover, researchers have also suggested that the sustained economic growth of a nation improves its global rankings (Acs \& Szerb, 2009; Bengoa \& Sanchez-Robles, 2003; Hazelkorn, 2014). In fact, the economic policies and global reputation are considered to be interrelated and hence, it is expected that the construct EGC is likely to be a key predictor of voter satisfaction (Ezrow \& Xezonakis, 2016). Thus, the following hypothesis was formulated: 
$\mathrm{H}_{4}$ : Economic and Global Considerations (EGC) positively affect Voter Satisfaction (VS)

\section{Perceived Risk (PR) and Economic and Global Considerations (EGC)}

The concept of risk perceived by voters covers uncertainty, anxiety and risk to future generations (Slovic, 2015). Voters perceive election process as a high-risk process because they believe that the selection of an incompetent government by them may disturb the economic stability of a country and may also damage its global reputation (Bauer, 1960; Dowling \& Satelin, 1994; O'Cass, 2002, 2003; O'Cass \& Pecotich, 2005). As a result, the construct perceived risk is expected to mobilize voters for higher participation in political process by making them believe that their election decisions has a bearing on the economy and global rankings of their country (Bauer, 1960; Dowling \& Satelin, 1994). Thus, the following hypothesis was formulated:

$\mathrm{H}_{5}$ : Perceived risk (PR) positively affects economic and global considerations (EGC) of voters.

\section{Social Considerations (SC) and Economic and Global Considerations (EGC)}

The construct of social considerations measures the concerns of voters regarding the underprivileged classes in their country. Farmers and women are the two underprivileged sections of the Indian society which capture a major part of the political debate in the country. Issues such as low prices of agricultural products, crop failure, high debt and poor income have led to around 300,000 farmer suicides in the last two decades (Basu, 2016; Kalokhe et al., 2017; Desai \& Mehta, 2017; Kaushal, 2018; Menon \& Allen, 2018; Sunder, 2018). With reference to women, issues such as domestic violence, women security, workplace harassment, etc. have been observed in the recent past (Kalokhe et al., 2017; Menon \& Allen, 2018). Previous researchers have indicated that voters perceive that the prevailing conditions of underprivileged sections of the society is a reflection of economic status of the country and affects reputation of the country at the global stage (Kapur \& Nangia, 2015; Vaishnav \& Swanson, 2015). Hence, the following hypothesis was formulated:

$\mathrm{H}_{6}$ : Social considerations (SC) positively affect economic and global concern (EGC) of the voters.

Based on the above hypotheses, the conceptual model presented in Figure 1 was proposed to be validated in the present study: 
Figure 1: Proposed Model

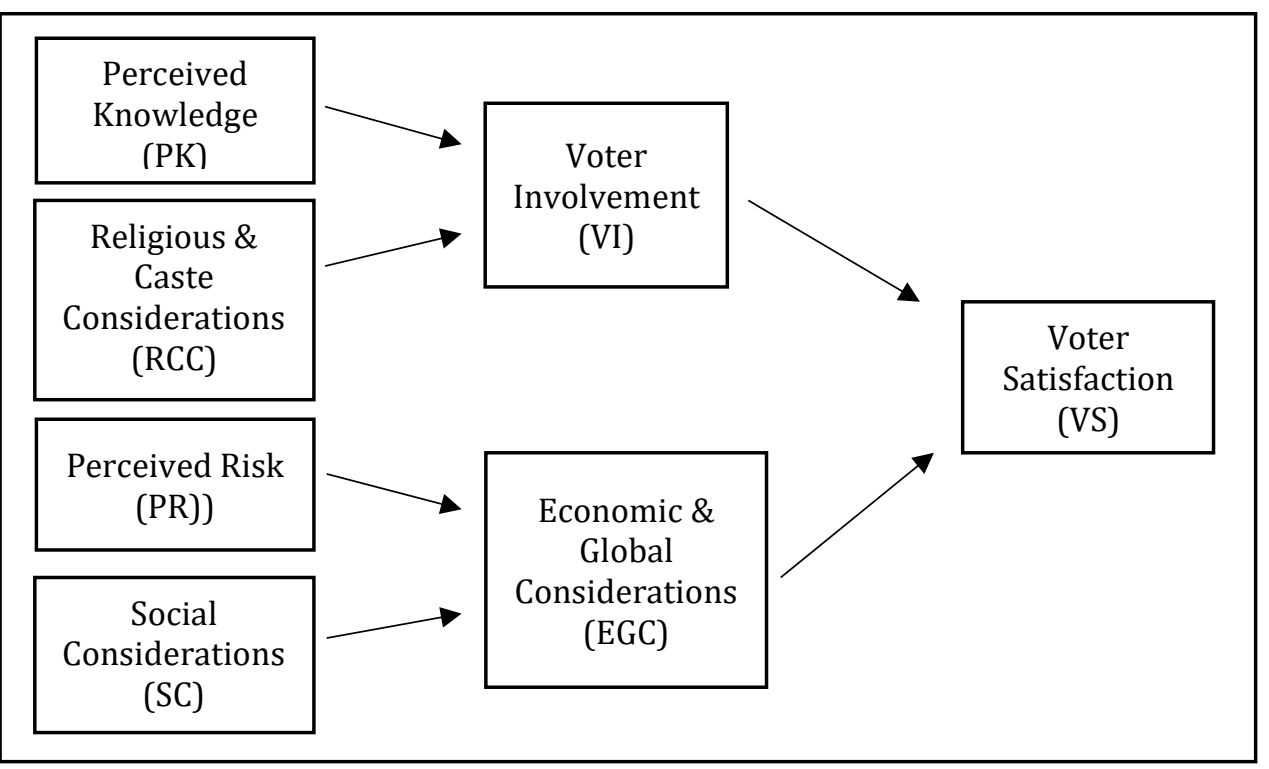

\section{Research Methods}

\section{Item Integration and Validation of the Scale}

The scale items were integrated from two sources. First, some items (Table 1) were adapted from the study by O'Cass and Pecotich (2005). These items (S13-S22; S29-S31) were added with a purpose to refine the scales proposed by O'Cass and Pecotich (2005) based on the Indian context. Second, items from S1 to S12 and from S23 to S28 were added by the researchers in the present study based on prevalent issues in the country such as economic conditions of India, global reputation of India, conditions of farmers, women, backward classes, minorities and issues specific to different caste and religion (Beg, 2017; Desai \& Mehta, 2017; Press Trust of India, 2017; Vaishnav, 2015; Vasudeva, 2017; Kaushal, 2018; Menon \& Allen, 2018; Singh, 2018; Sunder, 2018). These questionnaire items were based on a 5-point Likert scale $(1=$ strongly disagree; 5 = strongly agree $)$.

Before going for a final data collection, the questionnaire was distributed to a selected group of subject experts to check for proper wording, ease of understanding and to remove other inconsistencies. The experts were selected from a reputed university located in the northern region of the country and funded by the federal government of India. Based on the feedback from the experts, some of the items were rephrased to make them more relevant to the Indian context. 


\section{Sample}

Internationally, the United Nations has defined 'youth' as an individual within the age bracket of 15-24 years (Ministry of Youth Affairs and Sports, 2014). Based on the Indian context, the 'youth or young population' was defined by Ministry of Youth Affairs and Sports (2003) as the population that falls in the age bracket of 1335 years. This definition was revised by Ministry of Youth Affairs and Sports (2014) that considered population in the age bracket of 15-29 years as the young population.

For the purpose of sample selection, purposive sampling technique was employed. Several factors favour the use of purposive sampling technique in the present study. First, due to absence of a reliable and perfect sample frame, the researchers had to rely on their judgement to generate a sample that can represent the population (Khan \& Kirmani, 2018). Second, the purposive sampling technique ensures advantages such as generation of data from a large sample within a short duration of time and at a low cost (Gravetter \& Forzano, 2003; Malhotra \& Dash, 2011).

Recent studies have highlighted that the global youth is the frequent users of the internet and likes to remain online always (Abeler, Bekker, \& Falk, 2014; Ahmad \& Khan, 2017; Guth, Schmidt, \& Sutter, 2007; Jones 2002; Yoo \& Donthu 2001;). In India, 74\% of internet users are under the age of 35 years (Statista.com, 2016). The politicians have also identified online platforms as an effective medium for election campaigns, especially for the global and Indian youth (Chadha \& Guha, 2016). In light of above stated facts, it was believed that the online platforms can be employed to generate quality feedback from young population in India. Hence, it was decided to generate data for the present study from young internet users. In order to comply with the definition of 'youth' by Ministry of Youth Affairs and Sports (2014), care was taken to generate data only from the internet users who fall in the age bracket of $15-29$ years.

The data was generated from a sample comprising $56 \%$ male and $46 \%$ female respondents. Around 59\% of the respondents were below 25 years of age and other respondents $(41 \%)$ had already attained the age of 25 years. The respondents were a heterogeneous mix of different religions and caste. Majority of respondents (69\%) were affiliated to Hinduism followed by respondents affiliated to Islam (19\%), Christianity (4\%) and other religions (8\%). For caste affiliations, around $65 \%$ of respondents belonged to general category, 23\% to Other Backward Classes (OBC) and $12 \%$ to Scheduled Castes (SC) and Scheduled Tribes (ST). Sample comprised respondents belonging to northern (33\%), central (29\%), western (19\%), southern $(15 \%)$ and eastern $(4 \%)$ parts of the country. 


\section{Data Collection}

The methodology for data collection was adapted from the study by Bashir and Madhavaiah (2015). The questionnaire was created in Google-Docs and posted on various online pages, forum, pages and circles of students across the country. The survey ran for one month and stopped when the response rate dropped significantly. The survey resulted in generation of data from 263 respondents. Of these, 69 questionnaires were incomplete or unfit and hence, they were eliminated. Thus, only 194 questionnaires were declared fit for further analysis. Therefore, the final sample size for the present study was 194. This sample size is adequate for the studies employing statistical tools such as exploratory factor analysis and structural equation modeling (Comrey \& Lee, 1992; Gorsuch, 1983; MacCallum, Widaman, Zhang, \& Hong, 1999). This sample size also complies with the subject to variable ratio of 5:1, suggested and used by a significant number of previous researchers (Ahmad \& Khan, 2017; Hatcher, 1994).

\section{Findings}

\section{Exploratory Factor Analysis}

Exploratory factor analysis (EFA) was performed using SPSS 20.0 (see Table 1). Techniques such as the principal component analysis were employed for factor extraction and varimax rotation was used for the purpose of factor rotation. The items with factor loadings less than 0.4 were eliminated (Kline 1994; Hinkin, 1995; Buyukozturk, Akgün, Özkahveci, \& Demirel, 2004; Malhotra \& Dash, 2011; Metin, Yilmaz, Coskun, \& Birisci, 2012). The refined scale comprising of seven variables and 29 items was obtained. These variables are named as Economic and Global considerations (EGC), Religious and Caste Considerations (RCC), Social Considerations (SC), Voter Involvement (VI), Voter Satisfaction (VS) and Perceived Knowledge $(\mathrm{PK})$. The significant value $(<0.05)$ of Bartlett's Test of Sphericity (BTS) and acceptable value $(0.767 ;>0.6)$ of Kaiser-Meyer-Olkin (KMO) established the sample adequacy (Khan \& Adil, 2013; Malhotra \& Dash, 2011). The total variance for the EFA model was $70.1 \%$. The variables in the scale measure political sensitivity of voters and their satisfaction with the existing political environment.

The Cronbach's alpha values for all seven variables were found to be in the acceptable range of 0.771 to 0.916 . The first variable (EGC), represented by three items, had an alpha value of 0.771. The second and third variables (RCC and SC), represented by six-item and three-item scales, had alpha values of 0.916 and 0.836 , respectively. The fourth variable (VI), comprising three items, had an alpha value of 
0.877. The fifth (PR), sixth (VS) and seventh (PK) variables, each comprising three, four and seven item scales, had alpha values of $0.790,0.831$ and 0.902 respectively. Thus, the scale was found to be reliable with Cronbach's alpha values of more than 0.6 for all seven variables (Hair, Anderson, Tatham, \& Black 1998; Kerlinger \& Lee 2000; Khan \& Adil 2013).

Table 1: Items and EFA Results

\begin{tabular}{|c|c|c|c|}
\hline & Item & $\begin{array}{r}\text { EFA } \\
\text { Loading }\end{array}$ & Factor \\
\hline \multicolumn{4}{|c|}{ Items Retained after EFA; Total Variance $=\mathbf{7 0 . 1 \%}$} \\
\hline $1 *$ & $\begin{array}{l}\text { I believe that news of people dying of hunger } \\
\text { affects reputation of India at the global stage. }\end{array}$ & 0.705 & $\begin{array}{l}\text { Economic and } \\
\text { Global }\end{array}$ \\
\hline $2 *$ & $\begin{array}{l}\text { The rising unemployment is not a good news for } \\
\text { Indian economy. }\end{array}$ & 0.787 & $\begin{array}{l}\text { Considerations } \\
\text { (EGC) }\end{array}$ \\
\hline $3 *$ & $\begin{array}{l}\text { The incidents of communal violence negatively } \\
\text { affects global reputation of our country. }\end{array}$ & 0.563 & $\begin{array}{l}\text { Cronbach's } \\
\text { Alpha }=0.771\end{array}$ \\
\hline $4^{*}$ & $\begin{array}{l}\text { I prefer to vote for a candidate who I perceive as } \\
\text { most favorable to my religion. }\end{array}$ & 0.778 & $\begin{array}{l}\text { Religious and } \\
\text { Caste }\end{array}$ \\
\hline $5^{*}$ & $\begin{array}{l}\text { I prefer to vote for a political party which I } \\
\text { perceive as most favorable to my religion. }\end{array}$ & 0.769 & $\begin{array}{l}\text { Considerations } \\
\text { (RCC) }\end{array}$ \\
\hline $6^{*}$ & $\begin{array}{l}\text { I prefer to vote for a candidate who also belongs } \\
\text { to my own religion }\end{array}$ & 0.823 & $\begin{array}{l}\text { Cronbach's } \\
\text { Alpha }=0.916\end{array}$ \\
\hline $7 *$ & $\begin{array}{l}\text { In my opinion, the candidate of my religion can } \\
\text { better understand my problems. }\end{array}$ & 0.879 & \\
\hline $8^{*}$ & $\begin{array}{l}\text { In my opinion, the candidate of my caste can } \\
\text { better understand my problems. }\end{array}$ & 0.839 & \\
\hline $9 *$ & $\begin{array}{l}\text { I prefer to vote for a candidate who is also from } \\
\text { my own caste. }\end{array}$ & 0.830 & \\
\hline $10 *$ & $\begin{array}{l}\text { I prefer to vote for a candidate who I think } \\
\text { would work for improving the conditions of } \\
\text { farmers }\end{array}$ & 0.830 & $\begin{array}{l}\text { Social } \\
\text { Considerations } \\
\text { (SC) }\end{array}$ \\
\hline $11^{*}$ & $\begin{array}{l}\text { I prefer to vote for a political party which I think } \\
\text { would work for improving the conditions of } \\
\text { farmers }\end{array}$ & 0.879 & $\begin{array}{l}\text { Cronbach's } \\
\text { Alpha }=0.836\end{array}$ \\
\hline $12 *$ & $\begin{array}{l}\text { I prefer to vote for a candidate who I think } \\
\text { would work for improving the conditions of } \\
\text { women }\end{array}$ & 0.719 & \\
\hline 13\# & Politics is significant to me. & 0.806 & Voter \\
\hline $14 \#$ & Politics is a relevant part of my life. & 0.791 & Involvement \\
\hline $15 \#$ & Politics is personally important for me. & 0.745 & $\begin{array}{l}(\mathrm{VI}) \\
\text { Cronbach's } \\
\text { Alpha }=0.877\end{array}$ \\
\hline
\end{tabular}




\begin{tabular}{|c|c|c|c|}
\hline & Item & $\begin{array}{r}\text { EFA } \\
\text { Loading } \\
\end{array}$ & Factor \\
\hline $16 \#$ & There is lot hinging on election & 0.644 & \multirow{3}{*}{$\begin{array}{l}\text { Perceived Risk } \\
\text { (PR) } \\
\text { Cronbach's } \\
\text { Alpha }=0.790\end{array}$} \\
\hline $17 \#$ & $\begin{array}{l}\text { If a wrong candidate gets elected, there is a lot to } \\
\text { lose. }\end{array}$ & 0.882 & \\
\hline $18 \#$ & $\begin{array}{l}\text { If a wrong party gets elected, there is a lot to } \\
\text { lose. }\end{array}$ & 0.879 & \\
\hline $19 \#$ & $\begin{array}{l}\text { I am satisfied with the party I voted for in the } \\
\text { last election }\end{array}$ & 0.861 & \multirow{4}{*}{$\begin{array}{l}\text { Voter } \\
\text { Satisfaction } \\
\text { (VS) } \\
\text { Cronbach's } \\
\text { Alpha }=0.831\end{array}$} \\
\hline $20 \#$ & $\begin{array}{l}\text { I am satisfied with the politician I voted for in } \\
\text { the last election }\end{array}$ & 0.844 & \\
\hline $21 \#$ & I am satisfied with the politics in general. & 0.729 & \\
\hline $22 \#$ & $\begin{array}{l}\text { I am satisfied with the political parties in } \\
\text { general. }\end{array}$ & 0.731 & \\
\hline 23\# & I know a lot about politics. & 0.831 & \multirow{14}{*}{$\begin{array}{l}\text { Perceived } \\
\text { Knowledge } \\
(\mathrm{PK}) \\
\text { Cronbach's } \\
\text { Alpha }=0.902\end{array}$} \\
\hline 24\# & I consider myself as an expert on politics & 0.815 & \\
\hline $25 \#$ & $\begin{array}{l}\text { Compared to most people I know more about } \\
\text { politics }\end{array}$ & 0.821 & \\
\hline 26\# & I am knowledgeable about politics. & 0.798 & \\
\hline 27\# & $\begin{array}{l}\text { I try to keep myself up to date during the } \\
\text { election. }\end{array}$ & 0.567 & \\
\hline $28 \#$ & I spend a lot of time talking about politics. & 0.740 & \\
\hline 29\# & $\begin{array}{l}\text { I am regarded as a good source of information } \\
\text { about politics. }\end{array}$ & 0.840 & \\
\hline \multicolumn{3}{|c|}{ Items Not Retained after EFA } & \\
\hline $30^{*}$ & $\begin{array}{l}\text { The weakening of Indian rupee in comparison to } \\
\text { Dollar is a worrying trend. }\end{array}$ & $<0.40$ & \\
\hline $31 *$ & $\begin{array}{l}\text { The empowerment of Indian women is very } \\
\text { important for overall development of our } \\
\text { country. }\end{array}$ & $<0.40$ & \\
\hline $32 *$ & $\begin{array}{l}\text { It is very depressing for me to hear news of } \\
\text { farmers' distress in my country. }\end{array}$ & $<0.40$ & \\
\hline $33^{*}$ & $\begin{array}{l}\text { I prefer to vote for a candidate who I perceive as } \\
\text { most concerned about solving prevailing } \\
\text { economic problems }\end{array}$ & $<0.40$ & \\
\hline $34 *$ & $\begin{array}{l}\text { I prefer to vote for a political party who I } \\
\text { perceive as most concerned about solving } \\
\text { prevailing economic problems }\end{array}$ & $<0.40$ & \\
\hline $35^{*}$ & $\begin{array}{l}\text { I prefer to vote for a political party which I think } \\
\text { would work for improving the conditions of } \\
\text { women }\end{array}$ & $<0.40$ & \\
\hline
\end{tabular}




\begin{tabular}{|c|c|c|c|}
\hline & Item & $\begin{array}{r}\text { EFA } \\
\text { Loading }\end{array}$ & Factor \\
\hline $36 \#$ & I am interested in politics. & $<0.40$ & \\
\hline $37 \#$ & I am involved in politics. & $<0.40$ & \\
\hline 38\# & Voting has a degree of risk & $<0.40$ & \\
\hline
\end{tabular}

Notes: 1 . *Items added by the Researchers

2. \#Items from the study by O'Cass \& Pecotich (2005)

\section{Measurement Model}

Previous researchers have advocated that confirmatory factor analysis (CFA) should be followed by EFA as EFA fails to describe the cross loadings of items and correlation among the variables (Ahmad \& Khan, 2017; Ahire, Golhar, \& Waller, 1996; Khan \& Adil, 2013; Lee, 2008). Hence, CFA was performed on the seven factors using AMOS 20.0 (see Figure 2). The majority of the items was loaded on the intended variable with loadings greater than 0.5 (Ryu, Han, \& Jang, 2010). The loadings for items S6, S9, S22, S26 and S27 were poor and hence, these items were eliminated for further analysis. The result of model fit indices is presented in Table 2. The model fit indices were within the acceptable range (Gerbing \& Anderson, 1988; Hu \& Bentler, 1999; Hair, Black, Babin \& Anderson, 2010).

Table 2: Fit Indices of Measurement Model (CFA)

\begin{tabular}{lcc}
\hline Fit Index & $\begin{array}{c}\text { Recommended } \\
\text { Values* }\end{array}$ & $\begin{array}{c}\text { Observed } \\
\text { Values }\end{array}$ \\
\hline CMIN/df & $<0.30$ & 2.070 \\
GFI & 0.90 & 0.884 \\
AGFI & 0.80 & 0.846 \\
NFI & 0.90 & 0.875 \\
CFI & 0.90 & 0.930 \\
RMSEA & $<0.70$ & 0.061 \\
\hline
\end{tabular}

Note: *Sourced from Hu and Bentler (1998); Hooper et al. (2008);

Hair et al, (2010); Malhotra and Dash (2011)

For the purpose of reliability and validity, techniques such as average variance extracted (AVE) and composite reliability (CR) were employed (Fornell \& Larcker 1981; Hair et al., 2010). AVE values for all seven variables were above 0.5 , indicating adequate convergent validity (Fornell \& Larcker 1981; O'Leary-Kelly \& Vokurka 1998; Hair et al., 2010; Khan \& Adil 2013). The square root of AVE (diagonal values in Table 3) is greater that the 'inter-construct' correlation, confirming acceptable discriminant validity (Fornell \& Larcker, 1981; O’Leary-Kelly \& Vokurka, 1998; Hair et al., 2010; Khan \& Adil, 2013). The values for CR were also within acceptable 
range (>0.7) indicating adequate composite reliability (Fornell \& Larcker, 1981; Hair et al., 2010; Malhotra \&Dash, 2011).

\section{Figure 2: Measurement Model}

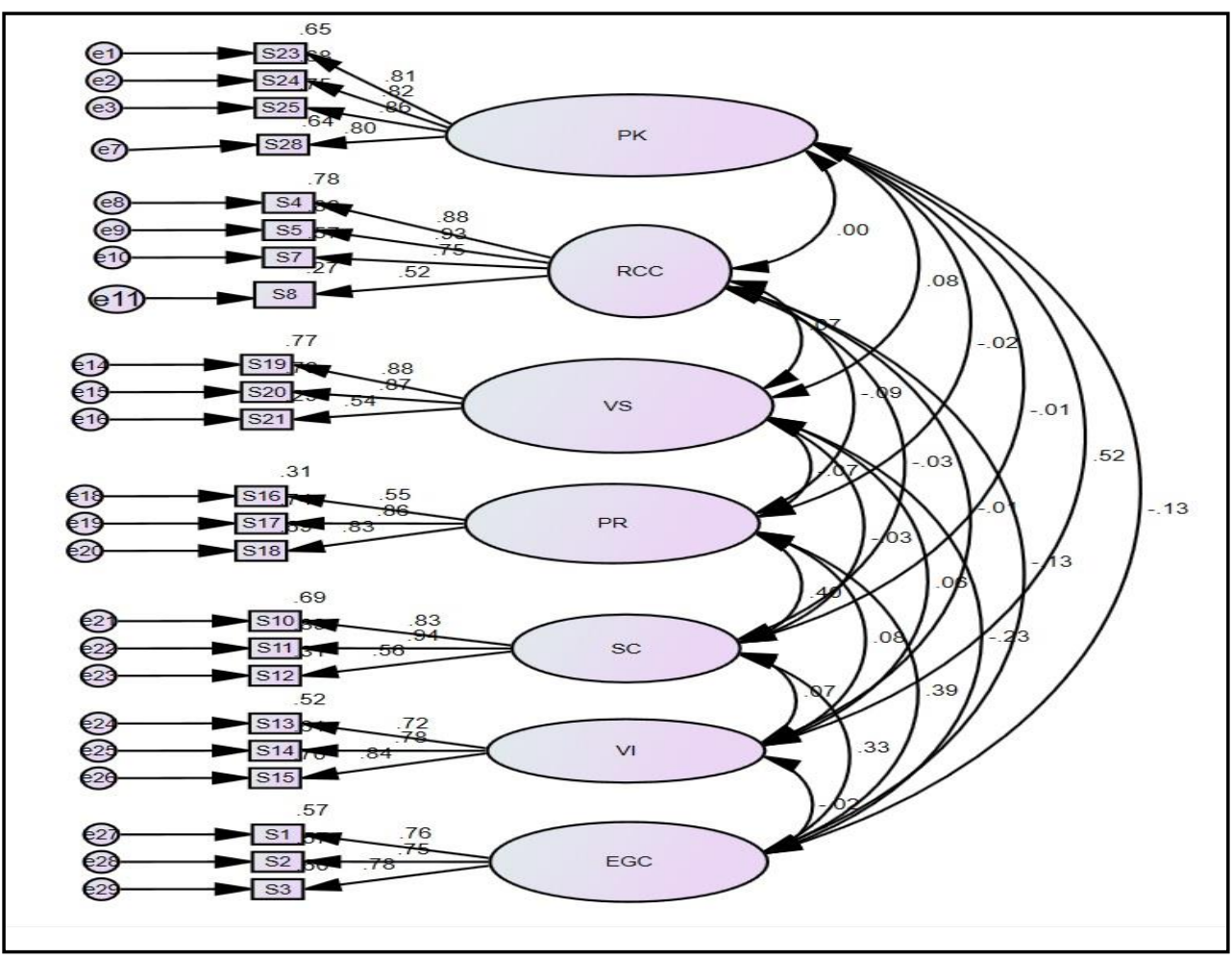

Table 3: Reliability and Validity

\begin{tabular}{lrrrrrrrrr}
\hline & CR & AVE & PK & RCC & VS & PR & SC & VI & EGC \\
\hline PK & 0.894 & 0.678 & 0.823 & & & & & & \\
RCC & 0.860 & 0.617 & -0.004 & 0.785 & & & & & \\
VS & 0.818 & 0.610 & 0.085 & 0.067 & 0.781 & & & & \\
PR & 0.801 & 0.582 & -0.024 & -0.093 & -0.072 & 0.763 & & & \\
SC & 0.831 & 0.631 & -0.009 & -0.027 & -0.030 & 0.398 & 0.794 & & \\
VI & 0.825 & 0.612 & 0.522 & -0.009 & 0.058 & 0.081 & 0.074 & 0.782 & \\
EGC & 0.806 & 0.581 & -0.130 & -0.129 & -0.227 & 0.388 & 0.335 & -0.017 & 0.762 \\
\hline
\end{tabular}

Note: $\mathrm{PK}=$ Perceived Knowledge; $\mathrm{RCC}=$ Religious and Caste Considerations; VS= Voter Satisfaction; $\mathrm{PR}=$ Perceived Risk; $\mathrm{SC}=$ Social Considerations; VI= Voter Involvement; EGC= Economic and Global Considerations

The study has validated the model presented in Figure 3. 


\section{Figure 3: Final Model}

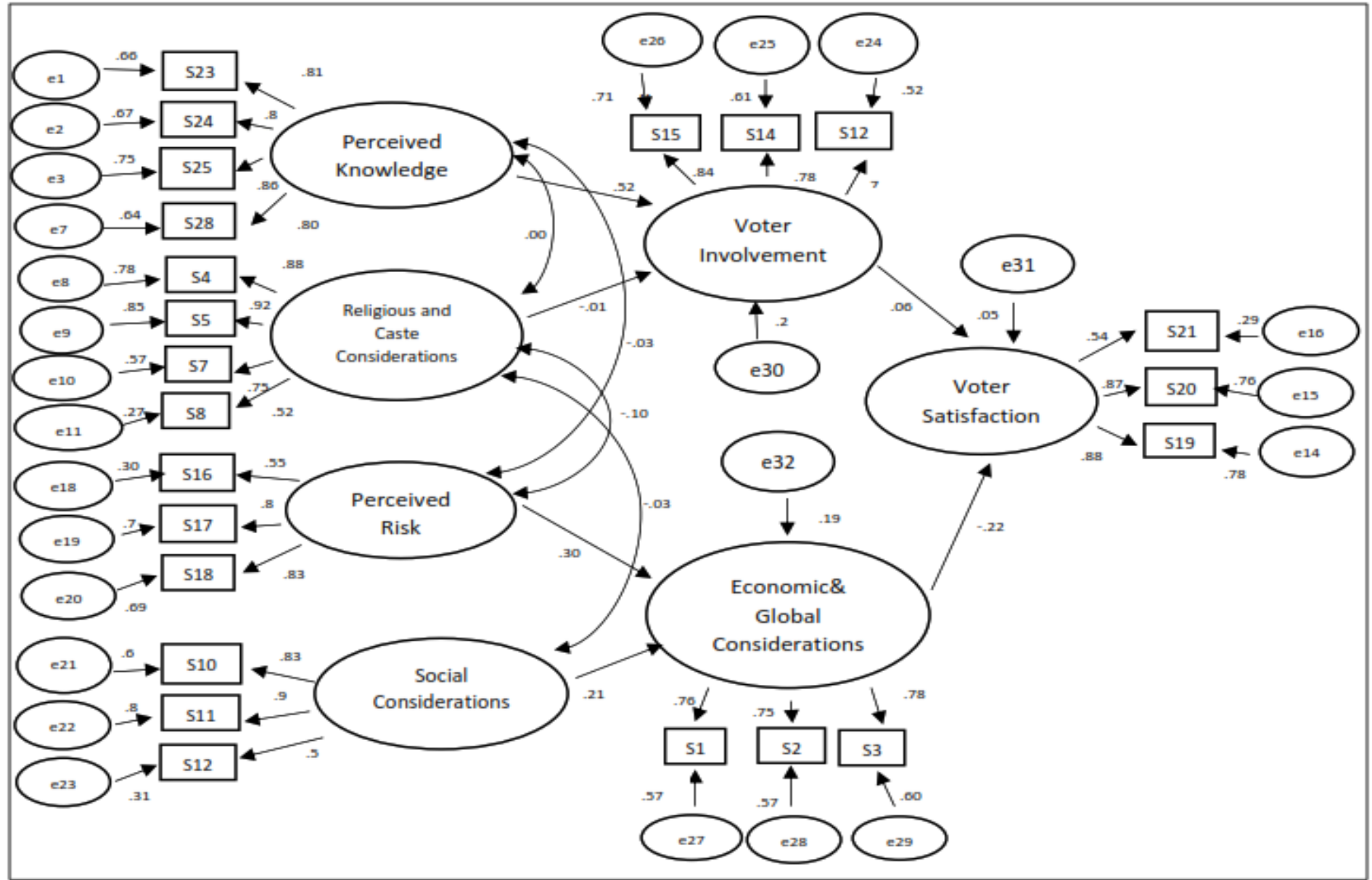


The model fit indices for structural modeling were also within acceptable range (CMIN/df=2.030; GFI=0.881; AGFI=0.849; $\mathrm{CFI=0.930;} \mathrm{RMSEA=0.060).} \mathrm{The} \mathrm{study}$ findings revealed that the construct voter involvement is not significantly linked to voter satisfaction $(p>0.05)$ suggesting that the hypothesis $\mathrm{H}_{1}$ was not supported. However, the construct EGC was observed to be significantly $(p<0.05)$ but negatively $(\beta=-0.222)$ linked to the construct VS. Thus, the hypothesis $\mathrm{H}_{4}$ was partially supported. The study findings also suggested that perceived knowledge (PK) is significantly $(p<0.05)$ and positively $(\beta=0.522)$ linked with voter involvement. But, the relationship between the religious and caste considerations (RCC) was not observed to be significant $(p>0.05)$ with voter involvement. Thus, the hypothesis $\mathrm{H}_{2}$ was supported but the hypothesis $\mathrm{H}_{3}$ was not supported. Both predictors (perceived risk and social considerations) of Economic and Global Consideration (EGC) were observed to be significantly $(p<0.05)$ and positively $((\beta=0.305$ and 0.212 respectively) related with EGC. Hence, the hypotheses $\mathrm{H}_{5}$ and $\mathrm{H}_{6}$ were supported.

\section{Discussion and Conclusion}

The present study is based on the premise that designing strong campaigns is crucial for winning elections in India and hence, political parties and leaders need to be aware of the complexities involved in decision making process of voters in India. In this regard, the study has two important contributions. First, the study has validated a scale for measuring the factors crucial for active participation of voters in the political process. In fact, the 23-item scale will improve the understanding of academicians and practitioners about the issues vital for determining voter participation in the political process. Second, the study also proposed and validated a model examining the linkages among the variables covering the 23 -item scale. This model will greatly help academicians and researchers for deeper understanding of the dynamics involved in satisfaction of voters and their eagerness to participate in the political process. The improved understanding of voters will also assist politicians in developing appropriate strategies. In fact, politicians may prioritize voter concerns by focusing on findings of the present study.

More specifically, the variable Economic and Global Considerations (EGC) was observed to be crucial for predicting voter satisfaction. Study findings revealed that more the voters are concerned about the economic status and global reputation of their country, difficult it would be for politicians to satisfy them with their policies. The incumbent government is required to emphasize on finding solutions for the economic problems and building a strong reputation for the country across the globe. This will create a positive perception among voters about the incumbent government and will 
contribute in increasing the voter satisfaction. This assertion find support in the recently held General Elections (2019) in India where it was noticed that the positive perceptions about the economic and foreign policies led to return of the incumbent government with a clear majority (Devlin, 2019).

The two variables that are observed to be crucial for predicting EGC are social considerations (SC) and Perceived Risk (PR). The present study has affirmed that the Indian politicians ought to design appropriate policies for the underprivileged sections of the society including farmers, women and other backward classes to create a positive perception among the voters with regard to economic status and global reputation of the country (Kalokhe et al., 2015; Kapur \& Nangia, 2015; Vaishnav \& Swanson, 2015; Basu, 2016; Menon \& Allen, 2018). Similarly, the present study also supports the previous findings that higher the risk perceived by voters in their election decisions, more concerned they will be for the economic and global reputation of their country (Bauer, 1960; Dowling \& Satelin, 1994; O'Cass, 2002; O'Cass \& Pecotich, 2005). In order to reduce concerns of Indian voters regarding economic status and global reputation of the country, politicians are required to propose strong economic and foreign policies in their election manifesto.

It was also observed in the present study that the perceived knowledge of voter results in their greater involvement in the election process. This finding supports the similar observation of the previous researchers in different cultural contexts (Delli Carpini \& Keeter, 1996; O’Cass \& Pecotich, 2005; Banwart, 2007; Stockemer \& Rocher, 2017). This is crucial in the Indian context where it has been observed that voter participation remain low in elections. This suggests that the key to increase involvement of voters in the political system is to increase their perceived knowledge i.e. making them believe that they possess sufficient knowledge about the political issues. However, findings of this study revealed that the higher voter involvement does not necessarily ensure the satisfaction of voters with the existing political system. This finding contradicts the observations of the studies in other countries and suggest that the Indian politicians ought to embrace different approach for increasing voter involvement and for increasing voter satisfaction (Richins \& Bloch, 1991; O’Cass, 2003; Geys et al., 2010).

In a nutshell, the present study has broken the myth that the Indian voters are guided by their concerns related to their religious and caste affiliations (Pande, 2003; Bhalotra et al., 2014; Harris, 2015; Heath et al., 2015; Huber \& Suryanarayan, 2016; Beg, 2017; Vaishnav, 2015). In fact, findings of the study suggest that the Indian voters adopt a realistic approach in their voting preferences and hence, Indian 
politicians must also employ a practical approach by focusing on issues such as economy, global reputation, progress of underprivileged sections of society and increasing voter trust.

\section{Limitations and Future Research Directions}

The scale and model validated in the present study can help politicians to design appropriate strategies for the election campaigns. However, there is a scope of improvement in some areas. First, the focus of the present study was on the urban voters. However, in India, politicians are required to modify their election strategies depending upon the specific needs of the voters living in villages. In fact, the fate of leaders and political parties in India is decided by the rural population, which is around 70\% of the total population in India (Ministry of Home Affairs, 2011; Lu, Yiu, \& Soman, 2016). Thus, the future researchers must undertake fresh studies for the rural voters. In fact, a comparative study on urban and rural voters will also provide useful insights.

Second, the study was based on responses from young voters only. The results may vary for other demographic categories such as voters belonging to different age groups, women voters, etc. Especially, the segment of women voters has attracted the attention of Indian politicians recently. Hence, the model presented in this study can also be revalidated for the women voters.

Third, the items to measure EGC, RCC and SC were added keeping current issues in mind. However, the issues may change with time and hence, future researchers may have to adapt items depending upon the issues prevailing at the time of their study. Finally, the present study is an example of cross sectional design that fails to capture the changes in voter preferences over a period of time. Thus, the future researchers may prefer a longitudinal study design to capture the changes over a period of time.

\section{Declaration of Conflicting Interests}

The authors declared no potential conflicts of interest with respect to the research, authorship, and publication of this article.

\section{References}

Abeler, J., Becker, A., \& Falk, A. (2014). Representative evidence on lying costs. Journal of Public Economics, 113(1), 96-104. doi:10.1016/ j.jpubeco. $\underline{2014.01 .005}$ 
Acs, Z. J., \& Szerb, L. (2009). The global entrepreneurship index (GEINDEX). Foundations and Trends ${ }^{\circledR}$ in Entrepreneurship, 5(5), 341-435. doi:10.1561/0300000027

Ahire, S. L., Golhar, D. Y., \& Waller, M. A. (1996). Development and validation of TQM implementation constructs. Decision Sciences, 27(1), 23-56. doi:10.1111/ j.1540-5915.1996.tb00842.x

Ahmad, A., \& Khan, M. N. (2017). Developing a website service quality scale: A confirmatory factor analytic approach. Journal of Internet Commerce, 16(1), 104-126. doi:10.1080/15332861.2017.1283927

Anderson, C. J. (2007). The end of economic voting? Contingency dilemmas and the limits of democratic accountability. Annual Review of Political Science, 10(1), 271-296. doi:10.1146/annurev.polisci.10.050806.155344

Antil, J. H. (1984). Conceptualization and operationalization of involvement. Advances in Consumer Research, 11(1), 203-209. Retrieved from http://www. acrwebsite.org/volumes/6243/volumes/v11/NA-11

Antunes, R. (2010). Theoretical models of voting behaviour. Exedra, 4(1). Retrieved from https://www.researchgate.net/publication/242653736_Theoretical_models _of_voting_behaviour

Banerjee, A., Green, D. P., McManus, J., \& Pande, R. (2014). Are poor voters indifferent to whether elected leaders are criminal or corrupt? A vignette experiment in rural India. Political Communication, 31(3), 391-407. doi:10.1080 $\underline{10584609.2014 .914615}$

Banerjee, S., \& Ray Chaudhuri, B. (2016). Factors responsible behind political brand preference: An empirical study on Indian voters. Marketing Intelligence \& Planning, 34(4), 559-582. doi:10.1108/MIP-05-2015-0095

Banwart, M. C. (2007). Gender and young voters in 2004: The influence of perceived knowledge and interest. American Behavioral Scientist, 50(9), 1152-1168. doi:10.1177/0002764207299362

Bashir, I., \& Madhavaiah, C. (2015). Consumer attitude and behavioural intention towards internet banking adoption in India. Journal of Indian Business Research, 7(1), 67-102. doi:10.1108/JIBR-02-2014-0013

Basu, D. (2016). Farmer suicides in India: Trends across major states, 1995-2011. Economic and Political Weekly. Retrieved from https://www.researchgate.net/ publication/303775605_Farmer_Suicides_in_India_Trends_across_Major_State $\underline{\text { s } 1995-2011}$

Basu, D., \& Misra, K. (2014). BJP s Demographic Dividend in the 2014 General Elections: An Empirical Analysis (Working Paper No. 2014-06). Department of Economics University of Massachusetts. 
Bauer, R. A. (1960). Consumer behavior as risk-taking. In R. S. Hancock RS (Ed.), Dynamic marketing for a changing world (pp. 389-398). Chicago: American Marketing Association.

Beg, A. M. (2017). The 2014 parliamentary elections in India: A study of the voting preferences of Muslims in Uttar Pradesh. The Round Table, 106(5), 567-576. doi:10.1080/00358533.2017.1368917

Bengoa, M., \& Sanchez-Robles, B. (2003). Foreign direct investment, economic freedom and growth: New evidence from Latin America. European Journal of Political Economy, 19(3), 529-545. doi:10.1016/S0176-2680(03)00011-9

Ben-Ur, J., (2007). Communication strategy to target low-involved voters in a US presidential election. Journal of Business and Society, 20(1-2), 217-231. Retrieved from https://web.b.ebscohost.com/abstract?direct=true\&profile =ehost $\underline{\& \text { scope }=\text { site } \& \text { authtype }=\text { crawler } \& j \mathrm{rnl}=10122591 \& \mathrm{AN}=35860565 \& \mathrm{~h}=\mathrm{mITGSny}}$ q3vPkkqCqusLfjiod4zXRZ1aCxv1RJuYcGfMCw0XTCAydCaupPtrvqd45tHk AIeJmo5wWbk1twCzOmQ\%3d\%3d\&crl=c\&resultNs=AdminWebAuth\&result Local=ErrCrlNotAuth\&crlhashurl=login.aspx\%3fdirect $\% 3$ dtrue $\% 26$ profile $\% 3 \mathrm{~d}$ ehost \%26scope\%3dsite\%26authtype\%3dcrawler\%26jrnl\%3d10122591\%26AN $\% 3 \mathrm{~d} 35860565$

Bhalotra, S., Clots-Figueras, I., Cassan, G., \& Iyer, L. (2014). Religion, politician identity and development outcomes: Evidence from India. Journal of Economic Behavior \& Organization, 104(1), 4-17. doi:10.1016/j.jebo.2013.09.006

Blalock, H. M. (1967). Toward a theory of minority-group relations. New York: Wiley.

Burton, S., \& Netemeyer, R. G. (1992). The effect of enduring, situational, and response involvement on preference stability in the context of voting behavior. Psychology and Marketing, 9(2), 143-156. doi:10.1002/mar. 4220090 $\underline{205}$

Buyukozturk, S., Akgün, Ö.E., Özkahveci, Ö., \& Demirel, F. (2004). The validity and reliability study of the Turkish version of the motivated strategies for learning questionnaire. Educational Sciences: Theory and Practice, 4(2), 207-239. Retrieved from https://s3.amazonaws.com/academia.edu.documents/8948832/ 85.PDF?response-content-disposition=inline\%3B\%20filename\%3DThe_Validi ty and Reliability Study of th.pdf\&X-Amz-Algorithm=AWS4-HMAC-SHA $\underline{\text { 256\&X-Amz-Credential=AKIAIWOWYYGZ2Y53UL3A\%2F2019100 1\%2Fus }}$ -east-1\%2Fs3\%2Faws4_request\&X-Amz-Date=20191001T112238Z\&X-A mzExpires $=3600 \& X-A m z-$ SignedHeaders $=$ host $\& X-A m z-$ Signature $=85263 \mathrm{f9f} 3 \mathrm{da}$ 10be5b30c9b92a1e2f5b4f1066f4c29c3342f274534198fb038e2

Campbell, A., Converse, P. E., Miller, W. E., \& Stokes, D. E. (1960). The American voter. New York: Willey. 
Ministry of Home Affairs (2011). Census of India. Government of India, New Delhi, India.

Central Statistics Office (2017). Youth in India. New Delhi: Author. Retrieved from http://mospi.nic.in/sites/default/files/publication_reports/Youth_in_India2017.pdf

Chadha, K., \& Guha, P. (2016). The Bhartiya Janata Party's online campaign and citizen involvement in India's 2014 election. International Journal of Communication, 10(1), 4389-4406.

Chandra, K. (2009). Why voters in patronage democracies split their tickets: Strategic voting for ethnic parties. Electoral Studies, 28(1), 21-32. doi:10.1016/j.electstu $\underline{\text { d.2008.06.006 }}$

Comrey, A. L., \& Lee, H. B (1992). A first course in factor analysis (2 ${ }^{\text {nd }}$ ed.). Hillsdale, NJ: Erlbaum.

Cook, E. (1994). Voter responses to women senate candidates. In E. Cook, S. Thomas, \& C. Wilcox (Eds.), The year of the woman: Myths and realities (pp. 217-236). Boulder, CO: Westview.

Cwalina, W., Falkowski, A., \& Newman, B. I. (2010). Towards the development of a cross-cultural model of voter behavior: Comparative analysis of Poland and the US. European Journal of Marketing, 44(3/4), 351-368. doi:10.1108/0309056 1011020462

Cwalina, W., Falkowski, A., Newman, B., \& Vercic, D. (2004). Models of voter behavior in traditional and evolving democracies: Comparative analysis of Poland, Slovenia, and US. Journal of Political Marketing, 3(2), 7-30. doi:10.130 0/J199v03n02_02

Dalton, R. J. (1984). Cognitive mobilization and partisan dealignment in advanced industrial democracies. Journal of Politics, 46(1), 264-284. doi:10.2307/ 2130444

Dalton, R. J. (2000). The decline of party identifications. In D. J. Russell \& M. P. Wattenberg (Eds.), Parties without partisans (pp. 19-36). New York: Oxford University Press.

Deka, K. (2019, March 22). Catch them young. India Today. Retrieved from https://www.indiatoday.in/magazine/cover-story/story/20190401-catching-them -young-1483605-2019-03-22

Delli Carpini, M. X., \& Keeter, S. 1996. What Americans know about politics and why it matters. New Haven, CT: Yale University.

Desai, S., \& Mehta, A. (2017, March 8). No economy for women. The Hindu. Retrieved from http://www.thehindu.com/opinion/lead/no-economy-for-women /article17424207.ece 
Devlin, K. (2019). A sampling of public opinion in India: Optimism persists, but concerns about terrorism and Pakistan loom large. Retrieved from https:// www.pewresearch.org/global/2019/03/25/a-sampling-of-public-opinion-inindia/

Dolan, K. (1998). Voting for women in the year of the woman. American Journal of Political Science, 42(1), 272-293. doi:10.2307/2991756

Dowling, G. R., \& Staelin, R. (1994). A model of perceived risk and risk-handling activity. Journal of Consumer Research, 21(2),119-134. doi:10.1086/209386

Downs, A. (1957). An economic theory of democracy. New York: Harper Collins Publishers.

Ehrenberg, A. (1997). How do consumers come to buy a new brand? Consumers have more or less steady propensities to buy a particular brand, but how do these evolve initially? Admap, 32(1), 20-24.

Ehrenberg, A. S. (1991). Politicians double jeopardy-A pattern and exceptions. Journal of the Market Research Society, 33(4), 347-353.

Erasmus, A. C., Boshoff, E., \& Rousseau, G. G. (2001). Consumer decision-making models within the discipline of consumer science: a critical approach. Journal of Consumer Sciences, 29(1), 82-90. Retrieved from https://www.ajol.info/ index.php/jfecs/article/view/52799

Ezrow, L., \&Xezonakis, G. (2016). Satisfaction with democracy and voter turnout: A temporal perspective. Party Politics, 22(1), 1-12. doi:10.1177/ $\underline{1354068814549335}$

Faber, R. J., Tims, A. R., \& Schmitt, K. G. (1993). Negative political advertising and voting intent: The role of involvement and alternative information sources. Journal of Advertising, 22(4), 67-76. doi:10.1080/0091336 7.199 $\underline{3.10673419}$

Falkowski, A., \& Cwalina, W. (2012). Political marketing: Structural models of advertising influence and voter behavior. Journal of Political Marketing, 11(12), 8-26. doi:10.1080/15377857.2012.642705

Fiorina, M. P. (1981). Retrospective voting in American national elections. New Haven: Yale University Press.

Fornell, C., \& Larcker, D. F. (1981). Evaluating structural equation models with unobservable variables and measurement error. Journal of Marketing Research, 18(1), 39-50. doi:10.1177\%2F002224378101800104

Franklin, M., Mackie, T. T., \& Valen, H. (1992). Electoral change. Responses to evolving social and attitudinal structures in western countries. Cambridge: Cambridge University Press.

Fyfe, I. (2009). Researching youth political participation in Australia: Arguments for an expanded focus. Youth Studies Australia, 28(1), 37-45. Retrieved from 
https://search.informit.com.au/documentSummary;dn=640259879397299; res=I ELAPA

Gad, K. A. (2014). The impact of political advertising through social networking sites on Egyptians' political orientations and choices. International Journal of Business and Social Research, 4(2), 1-17. doi:10.18533/ijbsr.v4i2.397

Gerbing, D. W., \& Anderson, J. C. (1988). An updated paradigm for scale development incorporating unidimensionality and its assessment. Journal of Marketing Research, 25(2), 186-192. doi:10.2307/3172650

Geys, B., Heinemann, F., \& Kalb, A. (2010). Voter involvement, fiscal autonomy and public sector efficiency: Evidence from German municipalities. European Journal of Political Economy,26(2), 265-278. doi:10.1016/j.ejpolec $\underline{0.2009 .11 .002}$

Giese, J. L., \& Cote, J. A. (2002). Defining customer satisfaction. Academy of Marketing Science Review, 2000(1), 1-24.

Gorsuch, R. L. (1983). Factor analysis ( $2^{\text {nd }}$ ed.). Hillsdale, NJ: Erlbaum.

Gravetter, F. J., \& Forzano, L. A. B. (2003). Research methods for the behavioral sciences. Boston, MA: Wadsworth/Thomson.

Guth, W., Schmidt, C., \& Sutter, M. (2007). Bargaining outside the lab-A newspaper experiment of a three-person ultimatum game. The Economic Journal, 117(518), 449-469. doi:10.1111/j.1468-0297.2007.02025.x

Hair, J. F., Anderson, R. E., Tatham, R. L., \& Black, W. C. (1998). Multivariate data analysis. Upper Saddle River, NJ: Prentice-Hall, Inc.

Hair, J.F., Black, W.C., Babin, B.J., and Anderson, R.E. (2010). Multivariate data analysis $\left(7^{\text {th }} \mathrm{Ed}\right)$. Upper Saddle River, NJ: Pearson Prentice Hall.

Hadjar, A., \& Beck, M. (2010). Who does not participate in elections in Europe and why is this? A multilevel analysis of social mechanisms behind nonvoting. European Societies, 12(4), 521-542. doi:10.1080/14616696.2010.483007

Harris, P., \& Lock, A. (2010). Mind the gap: The rise of political marketing and a perspective on its future agenda. European Journal of Marketing, 44(3/4), $297-$ 307. doi:10.1108/03090561011020435

Harriss, J. (2015). Hindu nationalism in action: The Bharatiya Janata Party and Indian politics. South Asia: Journal of South Asian Studies, 38(4), 712-718. doi:10.1080 /00856401.2015.1089826

Hatcher, L. (1994). A step-by-step approach to using the SAS® system for factor analysis and structural equation modeling. Cary, NC: SAS Institute, Inc.

Hazelkorn, E., (2014). Rankings and the global reputation race. New Directions for Higher Education, 168(1), 13-26. doi:10.1002/he.20110

Heath, O., Verniers, G., \& Kumar, S. (2015). Do Muslim voters prefer Muslim candidates? Co-religiosity and voting behaviour in India. Electoral Studies, 38(1), 10-18. doi:10.1016/j.electstud.2015.01.005 
Henn, M., Weinstein, M., \& Forrest, S. (2005). Uninterested youth? Young people's attitudes towards party politics in Britain. Political Studies, 53(3), 556-578. doi:10.1111/j.1467-9248.2005.00544.x

Heslop, L. (2014). Understanding India: The future of higher education and opportunities for international cooperation. British Council India. Retrieved from https://www.britishcouncil.in/sites/default/files/understanding_india.pdf.

Hinkin, T. R. (1995). A review of scale development practices in the study of organizations. Journal of Management,21(5), 967-988. doi:10.1177/ $\underline{014920639502100509}$

Hu, L.-T., \& Bentler, P. M. (1999). Cutoff criteria for fit indexes in covariance structure analysis: Conventional criteria versus new alternatives. Structural Equation Modelling: A Multidisciplinary Journal, 6(1), 1-55. doi:10.1080/ 10705519909540118

Huber, J. D., \& Suryanarayan, P. (2016). Ethnic inequality and the ethnification of political parties: Evidence from India. World Politics, 68(1), 149-188. doi:10. 1017/S0043887115000349

Huddy, L., \& Terkildsen, N. (1993). Gender stereotypes and the perception of male and female candidates. American Journal of Political Science, 37(1), 119-147. doi:10.2307/2111526

Sahu, J. (2014). General elections-2014, Information Bulletin, Research and Information Division, Lok Sabha Secretariat. Available at: $\underline{\text { http://164.100. } 47.193}$ /intranet/GeneralElections2014.pdf

Jain, S. K. (2019, March 12). First-time voters: A narrative about to change. Down to Earth. Retrieved from https://www.downtoearth.org.in/news/general-elections2019/first-time-voters-a-narrative-about-to-change-63535

Jasperson, A. E., \& Yun, H. J. (2007). Political advertising effects and America's racially diverse newest voting generation. American Behavioral Scientist, 50(9), 1112-1123. doi: $10.1177 / 0002764207300038$

Jones, S. (2002). The internet goes to college: How students are living in the future with today's technology. Washington, DC: Pew Internet and American Life Project.

Joshi, B., \& Kunduri, E. (2017). Youth in India: Prospects and challenges. Centre for Policy Research. Retrieved from http://www.cprindia.org/system/tdf/policybriefs/BRICS\%20CityLabII\%20Note\%20Joshi\%20\&\%20Kunduri.pdf?file=1\&t ype $=$ node $\&$ id $=6295 \&$ force $=1$

Kalokhe, A., del Rio, C., Dunkle, K., Stephenson, R., Metheny, N. Paranjape, A., \& Sahay, S. (2017). Domestic violence against women in India: A systematic review of a decade of quantitative studies. Global Public Health, 12(4), 498-513. doi:10.1080/17441692.2015.1119293 
Kapur, D., \& Nangia, P. (2015). Social protection in India: A welfare state sans public goods?. India Review, 14(1), 73-90. doi:10.1080/14736489.2015.1001275

Kaushal, N. (2018, January 8). View: The culture of freebies must give way to the use of technologies in farm. The Economic Times. Retrieved from https://economictimes.indiatimes.com/news/economy/agriculture/view-the-cult ure-of-freebies-must-give-way-to-the-use-of-technologies-in-farm/articleshow/ $\underline{62405641}$

Kerlinger, F. N., \& Lee, H. B. (2000). Foundations of behavioral research $\left(4^{\text {th }}\right.$ ed.). Stamford: Wadsworth.

Khan, M. N., \& Kirmani, M. N. (2018). Role of religiosity in purchase of green products by Muslim students. Journal of Islamic Marketing, 9(3), 504-526. doi: 10.1108/JIMA-04-2017-0036

Khan, M. N., \& Adil, M. (2013). Data analysis techniques in service quality literature: Essentials and advances. Serbian Journal of Management, 8(1), 95-112. doi:10. 5937/sjm8-3469

Ki, E. \&J., Hon, L. C. (2012). Causal linkages among relationship quality perception, attitude, and behavior intention in a membership organization. Corporate Communications: An International Journal, 17(2), 187-208. doi:10.1108/ 13563281211220274

Kiewiet, R. (1983). Macroeconomics and micropolitics: The electoral effects of economic issues. Chicago: University of Chicago Press.

Kline, P. (1994). An easy guide to factor analysis. London: Routledge.

Lazarsfeld, P. F., Berelson, B., \& Gaudet, H. (1944). The people's choice: How the voter makes up his mind in a presidential campaign. New York: Columbia University Press.

Lee, N. (2008). Developing and validating an instrument to assess performance of public sector organisations: A case study of Malaysian schools. Measuring Business Excellence, 12(3), 56-75. doi:10.1108/13683040810900403

Lewis-Beck, M. S., \& Stegmaier, M. (2000). Economic determinants of electoral outcomes. Annual Review of Political Science,3(1), 183-219. doi:10.1146/ annurev.polisci.3.1.183

Lu, J., Yiu, A., \& Soman, A. (2016). The Asian consumer-Indian consumer close up: Tapping the spending power of a young, connected urban mass. Retrieved from http://www.goldmansachs.com/our-thinking/pages/macroeconomic-insightsfolder/rise-of-the-india-consumer/report.pdf (accessed on November 1 2016).

MacCallum, R. C., Widaman, K. F., Zhang, S., \& Hong S. (1999). Sample size in factor analysis. Psychological Methods, 4, 84-99. doi:10.1037\%2F1082989X.4.1.84 
Malhotra, N. K., \& Dash, S. (2011). Marketing research: An applied orientation ( $^{\text {th }}$ ed.). Noida, USA: Pearson Education.

Manning, N. (2010). Tensions in young people's conceptualization and practice of politics. Sociological Research Online, 15(4), 1-10. doi:10.5153/sro.2256

Menon, S. V., \& Allen, N. E. (2018). The formal systems response to violence against women in India: A cultural lens. Community Psychology, 62(12), 51-61. doi:10.1002/ajcp.12249

Metin, M., Yilmaz, G. K., Coskun, K., \& Birisci, S. (2012). Developing an attitude scale towards using instructional technologies for pre-service teachers. TOJET: The Turkish Online Journal of Educational Technology, 11(1), 36-45. Retrieved from https://eric.ed.gov/?id=EJ976568

Ministry of Youth Affairs and Sports (2003). National youth policy, 2003. Retrieved from https://pib.gov.in/newsite/erelcontent.aspx?relid=519

Ministry of Youth Affairs and Sports (2014). National youth policy, 2014. Retrieved from https://www.yas.nic.in/sites/default/files/National-Youth-Policy-Documen $\underline{\text { t.pdf }}$

National Commission on Population (2006). Population projections for India and states 2001-2026. Retrieved from https://www.educationforallinindia.com/ Population Projection Report 2006.pdf

Newman, B. I. (1999). A predictive model of voter behavior: The repositioning of Bill Clinton. In B. I. Newman (Ed.), Handbook of political marketing (pp. 159173). Thousand Oaks, CA: Sage.

Newman, B. I. (2002). Testing a predictive model of voter behavior on the 2000 US presidential election. Journal of Political Marketing, 1(2-3), 159-173. doi:10.1300/J199v01n02_11

Newman, B. I., \& Sheth, J. N. (1985). A model of primary voter behavior. Journal of Consumer Research, 12(2), 178-187. doi:10.1086/208506

Newman, B. I., \& Sheth, J. N. (1987). A theory of political choice behavior, New York, NY: Praeger Publishers.

O'Cass, A. (2002). A micromodel of voter choice: Understanding the dynamics of Australian voter characteristics in a federal election. Psychology and Marketing, 19(12), 1025-1046. doi:10.1002/mar.10051

O'Cass, A. (2003). Electoral choice: The effect of voter control and involvement on satisfaction and voting stability. Journal of Political Marketing, 3(1), 61-85. doi:10.1300/J199v03n01 04

O'Cass, A., \& Nataraajan, R. (2003). At the polls: Continuing to explore voter psychology. Journal of Political Marketing, 2(2), 67-81. doi:10.1300/J199 $\underline{\mathrm{v} 02 \mathrm{n} 02 \quad 05}$ 
O'Cass, A., \& Pecotich, A. (2005). The dynamics of voter behavior and influence processes in electoral markets: A consumer behavior perspective. Journal of Business Research, 58(4), 406-413. doi:10.1016/j.jbusres.2003.08.003

O'Leary-Kelly, S. W., \& Vokurka, R. J. (1998). The empirical assessment of construct validity. Journal of Operations Management, 16(4), 387-405. doi:10.1016/S0272-6963(98)00020-5

O'Shaughnessy, N. (2001). The marketing of political marketing. European Journal of Marketing, 35(9/10), 1047-1057. doi:10.1108/03090560110401956

Palda, K. S. (1975). The effect of expenditure on political success. The Journal of Law and Economics, 18(3), 745-771. doi:10.1086/466837

Pande, R. (2003). Can mandated political representation increase policy influence for disadvantaged minorities? Theory and evidence from India. American Economic Review, 93(4), 1132-1151. doi:10.1257/000282803769206232

Peng, N., \& Hackley, C. (2009). Are voters, consumers? A qualitative exploration of the voter-consumer analogy in political marketing. Qualitative Market Research: An International Journal, 12(2), 171-186. doi:10.1108/13522750910948770

PTI (2017, February 9). Religious minorities, Dalits face discrimination in India: Report. The Economic Times. Retrieved from https://economictimes. indiatimes.com/news/politics-and-nation/religious-minorities-dalits-face-discri mination-in-india-report/articleshow/57055700.cms

Richins, M., \& Bloch, P. (1991). Post-purchase product satisfaction: Incorporating the effects of involvement and time. Journal of Business Research, 23(1), 145158. doi:10.1016/0148-2963(91)90025-S

Rothschild, M. L. (1978). Political advertising: A neglected policy issue in marketing. Journal of Marketing Research, 15(1), 58-71. doi:10.1177/002224377801500108

Ryu, K., Han, H., \& Jang, S. (2010). Relationships among hedonic and utilitarian values, satisfaction and behavioral intentions in the fast-casual restaurant industry. International Journal of Contemporary Hospitality Management, 22(3), 11416-432. doi:10.1108/09596111011035981

Singh, A. (2018, February 9). Rupee weakens further; Drops 16 paise against US dollar as Sensex loses over 550 points. Financial Express. Available at https://www.financialexpress.com/market/rupee-weakens-further-drops-16-pais e-against-us-dollar-as-sensex-loses-over-550-points/1059292/

Slovic, P. (2015). Understanding perceived risk: 1978-2015 . Environment: Science and Policy for Sustainable Development, 58(1), 25-29. doi:10.1080/ 00139157.2016 .1112169

Statista.com. (2016). Distribution of internet users in India in 2016 and 2020, by age group. Retrieved from https://www.statista.com/statistics/751005/india-share-ofinternet-users-by-age-group/ 
Stockemer, D., \& Rocher, F. (2017). Age, political knowledge and electoral turnout: A case study of Canada. Commonwealth \& Comparative Politics, 55(1), 41-62. doi:10.1080/14662043.2017.1252896

Sunder, S. (2018, January 29). Indian economic survey 2018: Farmers gain as agriculture mechanization speeds up, but more $\mathrm{R} \& \mathrm{D}$ needed. The Financial Express. Retrieved from https://www.financialexpress.com/budget/indiaeconomic-survey-2018-for-farmers-agriculture-gdp-msp/1034266/

Tate, K. (1993). From protest to politics: The new black voters in American elections. Cambridge: Russell Sage, Harvard University Press.

Vaishnav, M. (2015). Understanding the Indian voter. Carnegie Endowment for International Peace. Available at: https://carnegieendowment.org/files/BriefMilan-Indian_Voter.pdf

Vaishnav, M., \& Swanson, R. (2015). Does good economics make for good politics? Evidence from Indian states. India Review, 14(3), 279-311. doi:10.1080/ $\underline{14736489.2015 .1066218}$

Vasudeva, V. (2017, December 23). Why are farmers distressed across India?. The Hindu. Retrieved from http://www.thehindu.com/news/national/whyare-farmersdistressed-across-india/article22267501.ece

Wattenberg, M. P. (1994). The decline of American political parties, 1952-1992. Cambridge, MA: Harvard University Press.

Winchester, T., Hall, J., \& Binney, W. (2015). Evaluating young adult voter decisionmaking involvement within a compulsory political system. Qualitative Market Research: An International Journal, 18(3), 252-277. doi:10.1108/QMR-092013-0061

Yoo, B., \& Donthu, N. (2001). Developing a scale to measure the perceived quality of an Internet shopping site (SITEQUAL). Quarterly Journal of Electronic Commerce, 2(1), 31-45. doi:10.1.1.335.5127

Zaichkowsky, J. L. (1985). Measuring the involvement construct. Journal of Consumer Research, 12(3), 341-352. doi:10.1086/208520 